\title{
DURABILITY OF Pinus elliottii WOOD IMPREGNATED WITH QUEBRACHO COLORADO (Schinopsis balansae) BIO-PROTECTIVES EXTRACTS AND CCA
}

\author{
Aldo C. Bernardis ${ }^{1}$; Orlando Popoff ${ }^{1}$
}

\begin{abstract}
Some wood preservatives have a warning due to environmental restrictions and risks to man health. The aim of this study is to determine the performance of non impregnated and impregnated wood with a CCA salt and a bio-protective made from "quebracho colorado", when facing the action of fungi responsible for white rot decay by Pycnoporus sanguineus and brown rot attack by Gloeophyllum sepiarium. Wood samples were impregnated with different solutions by vacuum-pressure method. The design was in complete blocks at random with five repetitions. The treatments were $\mathrm{T}_{0}$ : non impregnated blank sample; impregnated $\mathrm{T}_{1}$ : CCA; $\mathrm{T}_{2}$ Colatan IPG-F, $\mathrm{T}_{3}$ : Colatan IPG-C, $\mathrm{T}_{4}$ : Colatan IPG-C, with retentions of: $6,18,9$ and $25 \mathrm{~kg} \mathrm{~m}^{-3}$ respectively. The variable was wood weight loss. Preservative $\mathrm{CCA}$ and bio-protective Colatan IPG-C increased the resistance to fungal degradation in lab assay, changing from non-resistance to very resistant (Findlay criterion), guaranteeing the biodegradation process inhibition.
\end{abstract}

Keywords: Wood protection, white rot, brown rot, tannin, acquired durability.

\section{INTRODUCTION}

Pinus elliottii tree is widespread in Corrientes and Misiones provinces forestations and on a smaller scale in other provinces of Argentina. The P. elliottii wood has different uses: the thinning crop is used in the cellulose pulp industry, chipboard panels and boards of MDF (Medium Density Fiberboard) kind. The main part of the wood harvest is set for sawmill.

The physico-mechanical, aesthetic and natural durability properties determine the uses assigned for the wood (Keil et al.2006). Wood of naturally low durability is treated with different protective agents to increase its resistance to degradation and it allows to broaden its uses. This practice of wood protection is defined as acquired durability (Zabel and Morrell 1992).

Wood durability may be calculated in a lab by means of standardized assays of accelerated degradation using the soil block technique (IRAM 9518, 1962; ASTM - D 2017, 1981).

Wood protection is a practice that allows increasing its durability in use and to reduce the maintenance costs caused by the frequent replacement of spoiled pieces of wood (FAO 1986).

Some of the substances used as chemical preservatives have warning due to environmental restrictions and thus there is a search for alternative techniques which can extend wood service life and which are, at the same time, less harmful to the environment and the man.

\footnotetext{
Facultad de Ciencias Agrarias UNNE. Sargento Cabral 2131. C.P. 3400 Corrientes. Argentina

Corresponding author: qaaber@agr.unne.edu.ar

Received: 28.10.2008. Accepted: 15.04.2009.
} 
With regard to tannin, there is no evidence that tannin has a specific function in the metabolism of plants, though its importance in the plant defense mechanisms against insects and rot fungi is acknowledged (Pearce 1996). The enzymatic attack derived from the metabolism of the fungi or bacteria colonizing wood may be substantially inactive or diminished in the presence of tannin (Gonzalez Laredo 1996).

The aim of this study was to determine the performance of P. elliottii wood without protectives, either and impregnated with CCA salt solution type c and "quebracho colorado" extract (due to its tannin content) based bio-protectives strengthened with minerals against, the actions of the white rot fungus Pycnoporus sanguineus and the brown rot fungus Gloephyllum sepiarum in lab tests.

\section{MATERIALS AND METHODS}

The wood used for the construction of test tubes was obtained from a 26 years old P. elliottii plantation, on sandy soil, located in San Miguel district, Corrientes province, Argentina (27'59'11" S and $\left.57^{\circ} 26^{\prime} 38^{\prime \prime} \mathrm{W}\right)$. From five trees were sawed five boards of $2.5 \times 7 \times 50 \mathrm{~cm}$. The stove drying took place until $25 \%$ humidity content.

The protectives used were: 1) CCA type c aqueous solution at 5\%. 2) Colatan IPG-F and Colatan IPG-C. Natural hydro soluble products made with "quebracho colorado" extract strengthened with mineral salts as the basic ingredient and tannin fixer to avoid wash out. Colatan IPG is a trademark product of UNITAN SAICA.

The wood boards were impregnated by the vacuum pressure method by means of the Bethell method (traditional full cell) in a lab autoclave. A loading dozer was made for each impregnation, weighing the volume and weight of each piece of wood and the concentration of the preserving solution in order to determine the individual retention. The working conditions were: initial void: $600 \mathrm{~mm} \mathrm{Hg}$ during 30 min., filling up the autoclave, $5 \mathrm{~min}$. pressure cycle: $5.5 \mathrm{~kg} \mathrm{~cm}^{-2}$ during $30 \mathrm{~min}$. Autoclave draining: 5 min. final void: $580 \mathrm{~mm} \mathrm{Hg} 20 \mathrm{~min}$.

The impregnated wood was placed in a dry room, under ceiling and with natural air circulation until equilibrium humidity of about 18\%. Fifty wood blocks, 5 per treatment, of $3 \times 1 \times 0.5 \mathrm{~cm}$, were prepared out of this impregnated and non-impregnated wood after it had been brushed according to IRAM 9518 Regulation (1962). Only blocks without nodes, stains or any other fault (deep splits or crakes) were used.

\section{Assay Design}

The design was in complete blocks at random with five repetitions and the treatments were:

$\mathrm{T}_{0}=$ non impregnated blank sample (control); $\mathrm{T}_{1}$ : impregnated with CCA type c with a $6 \mathrm{~kg} \mathrm{~m}^{-3} \mathrm{re}-$ tention; $\mathrm{T}_{2}$ impregnation with Colatan IPG-F with a $18 \mathrm{~kg} \mathrm{~m}^{-3}$ retention; $\mathrm{T}_{3}$ : impregnation with Colatan IPG - C with a $9 \mathrm{~kg} \mathrm{~m}^{-3}$ retention, and $\mathrm{T}_{4}$ : impregnation with Colatan IPG-C with a $25 \mathrm{~kg} \mathrm{~m}^{-3}$ retention. The variable measured was the wood blocks weight at the beginning and at the end of the experiment.

Before the impregnation process, the volume $(\mathrm{V})$ was determined and the wood blocks were weighed before (Pi) and after (Pf) impregnation. The absorption values $\left(\mathrm{A}\right.$ in $\mathrm{kg} \mathrm{m}^{-3}$ ) were obtained and

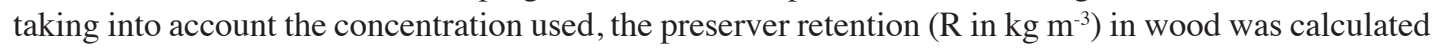
by the following formulas:

$$
A=\frac{P_{f}-P_{i}}{V}, R=\frac{A \times C \%}{100}
$$




\section{Fungi used and culturing}

Each one strain of Gloeophyllum sepiarium (brown rot) and Pycnoporus sanguineus (white rot), was obtained from the "Instituto de Botánica del Nordeste" (CTES Conicet-UNNE).

Pre-culturing of the fungi was performed in Petri dishes with $2.5 \%$ agar and $1.5 \%$ malt extract at $27^{\circ} \mathrm{C}$ for 2 weeks.

$50 \mathrm{ml}$ of medium was put in 50 plastic flasks with lid; after that they were sterilized at 1,5 pressure air $30 \mathrm{~min}$.

The wood blocks were stove dried at $103^{\circ} \mathrm{C}$ for 24 hours, set in a drier for cooling and were weighed $\mathrm{P}(\mathrm{i})$. Before inoculation they were sterilized in a stove at $103^{\circ} \mathrm{C}$ for during $30 \mathrm{~min}$. Flasks containing each one block were inoculated with a about $1 \mathrm{~cm}^{2}$ agar block with the mycelium under a laminar air flux, Fig. 1. The flasks were sealed and placed in a stove at $27^{\circ} \mathrm{C}$ for 3 months.



Figure 1. Fungi and culture flasks before inoculation.

\section{Harvesting}

After the set time, the wood blocks were sampled and the remnant of the mycelium was withdrawn; they were stove dried at $103^{\circ} \mathrm{C}$ for $24 \mathrm{~h}$, placed in a dehydrator and weighed $\mathrm{P}(\mathrm{f})$. Taking into account the initial and final weight difference, the mass (weight) loss percentage caused by the fungus was determined following this formula:

$$
P_{P}(\%)=\frac{P_{i}-P_{f} \times 100}{P_{i}}
$$

Findlay's criterion (1951), which establishes the relation between weight loss percentage caused by fungi and the wood strength grade, was followed (Table 1). 
Table 1: Wood grading according to the weight loss in \% caused by xylophagus fungi and its strength grade.

\begin{tabular}{|c|c|}
\hline Weight loss & Durability grade or Resistance Category \\
\hline Lower than 5 & Very resistant \\
\hline 5 to 10 & Resistant \\
\hline 10 to 20 & Moderately resistant \\
\hline 20 to 30 & Not resistant \\
\hline Higher than 30 & Perishable or without resistance \\
\hline
\end{tabular}

\section{RESULTS AND DISCUSSION}

\section{Brown Rot Decay}

The brown rot fungus Gloeophyllum sepiarium rapidly colonized the non-impregnated wood pine blocks $\left(\mathrm{T}_{0}\right)$, those impregnated with Colatan IPG-F $\left(\mathrm{T}_{2}\right)$ and those with Colatan IPG-C as well $(8 \mathrm{~kg}$ $\mathrm{m}^{-3}$ retention) $\left(\mathrm{T}_{3}\right)$. There was no colonization of the blocks with CCA type $\mathrm{c}\left(\mathrm{T}_{1}\right)$ and Colatan IPG-C (25 $\mathrm{kg} \mathrm{m}^{-3}$ retention) $\left(\mathrm{T}_{4}\right)$, (Figure 2 ).

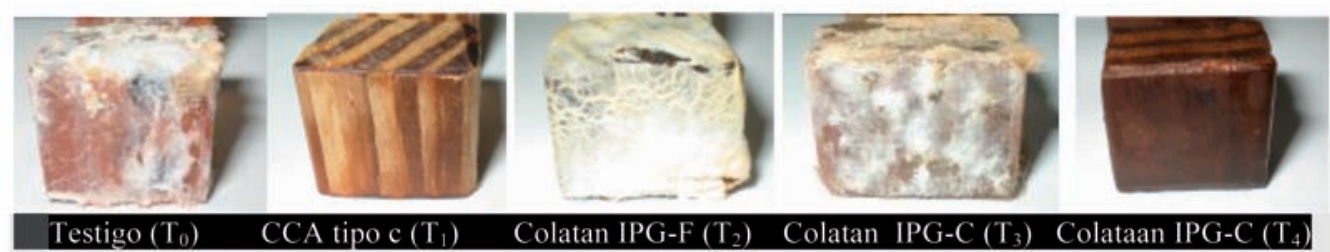

Figure 2. View on the blocks 3 months after inoculation with Gloeophyllum sepiarium.

Three months after the inoculation, the wood degradation in the control was simply observed with naked eyes (Figure 3) and there was no evidence of degradation symptoms of the tissues of wood impregnated with the different protective solutions. With the help of a magnifying glass, the woody tissue degradation was observed in detail (Figure 4).

As it was expected, the greater weight loss $38.80 \%$ was registered in the control blocks, with statistically significant differences $(\mathrm{p}<0,05)$ regarding the rest of the treatments. Bobadilla et al. (2007) found similar values in P. taeda L. The results obtained are in accordance with the IRAM 9600 (1998) regulation that classifies the resinous pine wood as Class 3: not very durable against fungi. According to Findlay scale, ASTM D-2017 (1981), wood with fungal weight loss $>$ to $30 \%$ (Table 1) is classified as perishable or without resistance. 


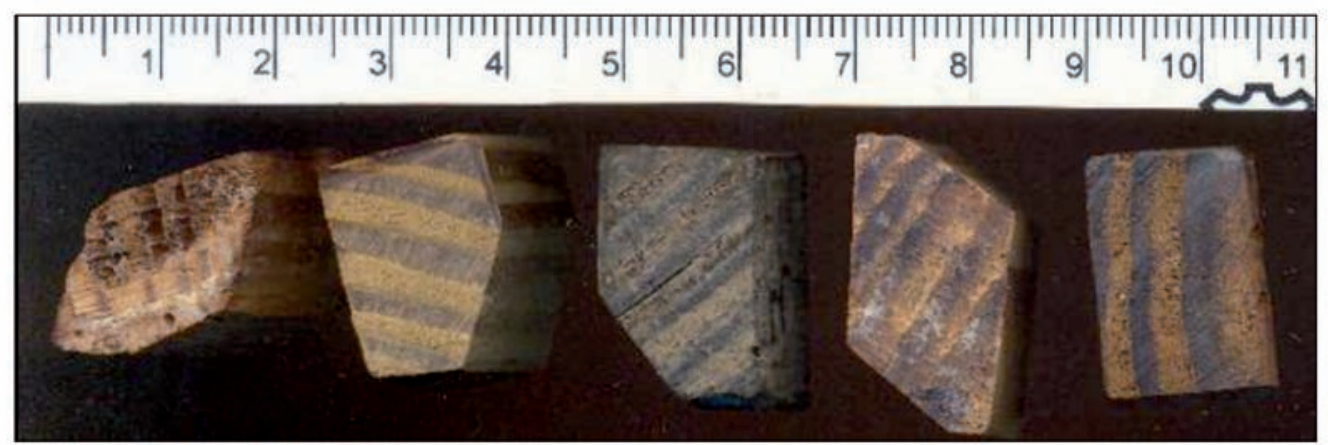

Figure 3. Brown rot effects on the different blocks after 3 months.

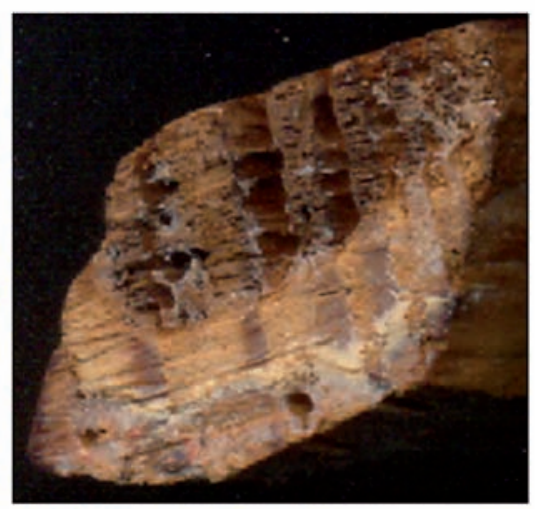

Figure 4. Details of degradation by Gloeophyllum sepiarium on non-impregnated pinewood $\left(\mathrm{T}_{0}\right)$.

The Colatan IPG-F treatment showed weight loss of $29.26 \%$, with significant differences as regard the rest of the treatments. This substance reduces the weight loss for 9,54\% with regard to the blank sample, achieving an increase in wood durability. According to Findlay scale, ASTM D 2017 (1981) wood turns to be non resistant (weight loss between 10 to $30 \%$ ).

A smaller weight loss of $0.72 \%$ was registered with the CCA type c treatment variation index was $28.92 \%$. This treatment $\left(\mathrm{T}_{1}\right)$ and the ones with Colatan IPG-C $\left(\mathrm{T}_{3}\right.$ and $\left.\mathrm{T}_{4}\right)$ did not show significant differences (Table 3).

Pine wood impregnated with CCA type c, Colatan IPG-C in was highly resistant to degradation (weight loss rate $0-10 \%$ ) when exposed to the brown rot fungus.

The protection observed due to the weight loss (less than 5\%) would allow the use of this wood in high risk conditions when confronting to brown rot fungi. 
Table 3. Treatments, protectives, retentions, weight losses and variation index of pine wood after brown rot attack and durability grade (Findlay 1951).

\begin{tabular}{|c|c|c|c|c|c|}
\hline Treatments & Protectives & $\begin{array}{c}\text { Retention } \\
\mathbf{K g ~ m}^{-3}\end{array}$ & $\begin{array}{c}\text { Average Weight } \\
\text { Loss \% }\end{array}$ & $\begin{array}{c}\text { Variability } \\
\text { Index (CV\%) }\end{array}$ & $\begin{array}{c}\text { Durability } \\
\text { Grade }\end{array}$ \\
\hline $\mathrm{T}_{0}$ & Control & 0.00 & $38.80 \mathrm{c}$ & 21.45 & Non-resistant \\
\hline $\mathrm{T}_{1}$ & CCA type c & 6.00 & $0.72 \mathrm{a}$ & 28.92 & Very resistant \\
\hline $\mathrm{T}_{2}$ & Colatan IPG-F & 18.00 & $29.26 \mathrm{~b}$ & 5.92 & Non-resistant \\
\hline $\mathrm{T}_{3}$ & Colatan IPG-C & 9.00 & $4.31 \mathrm{a}$ & 20.94 & Very resistant \\
\hline $\mathrm{T}_{4}$ & Colatan IPG-C & 25.00 & $4.68 \mathrm{a}$ & 3.82 & Very resistant \\
\hline
\end{tabular}

Different letters indicate significant differences $(p<0,05)$.

\section{White Rot Decay}

The white rot fungus Pycnoporus sanguineus colonized the wood rapidly and grew abundantly on the non-impregnated pine wood blocks. It colonized the Colatan IPG-F and Colatan IPG-C blocks ( 9 $\mathrm{kg} \mathrm{m}^{-3}$ retention) in a lesser grade. There was no colonization of blocks impregnated with CCA type c and Colatan IPG-C (25 kg m${ }^{-3}$ retention) (Figure 5).

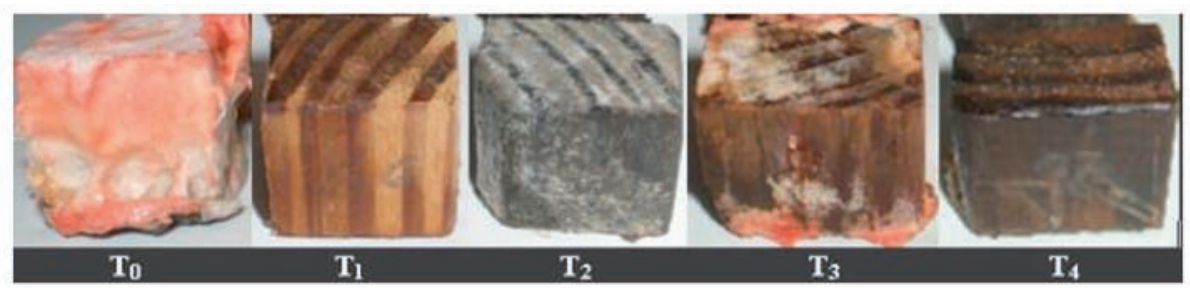

Figure 5. View on the test tubes after 3 months of culture with Pycnoporus sanguineus. Abundant colonization in the pinewood without impregnation $\left(\mathrm{T}_{0}\right)$.

At the end of the assay, tissue degradation symptoms in the control treatment were observed at a glance.

Pinewood resistance assayed in the different treatments before white rot attack (Pycnoporus sanguineus), measured according to the weight loss of the wood blocks is shown in Table 4.

The greatest weight loss was measured for the controls $\mathrm{T}_{0}$, with a $25.84 \%$, with statically significant differences $(p<0.05)$ regarding the rest of the treatments (Table 4). Moreno et al. (2002) registered in Caribbean pine wood boards $18.51 \%$ weight loss by white rot fungi. Bobadilla et al. (2007) found $34.63 \%$ weight loss in P. taeda L. wood. These percentages are high taking into consideration that conifers contain only guayacil lignin (Highley 1983; Blanchette et al. 1990) and that Pycnoporus sanguineus has preference for hardwoods that have lignin of the syringyl type (Eaton and Hale 1993) that is more easily degraded than conifer lignin (Eriksson et al. 1990).

Similarly, the minor attack of the white rot fungus can be explained by the fact that the pine has lignin of the guayacil type. 
The IRAM 9600 (1998) regulation classifies the resinous pine wood (P. elliottii and P. taeda) as not very durable with an estimated service life of 5 and 10 years, taking into account the heartwood against fungi (Class 3). The results of the controls are in accordance with this classification. When compared to Findlay's scale (1951) the results show that pinewood is not resistant to white rot.

Table 4. Behavior of pinewood samples impregnated with different protectives and retentions against a white rot fungus, and the durability grade (Findlay 1951).

\begin{tabular}{|c|c|c|c|c|c|}
\hline Treatments & Protectives & $\begin{array}{c}\text { Retention } \\
\mathbf{K g ~ m}^{-3}\end{array}$ & $\begin{array}{c}\text { Average Weight } \\
\text { Loss \% }\end{array}$ & $\begin{array}{c}\text { Variability } \\
\text { Index (CV\%) }\end{array}$ & $\begin{array}{c}\text { Durability } \\
\text { Grade }\end{array}$ \\
\hline $\mathrm{T}_{0}$ & Control & 0.00 & $25.84 \mathrm{c}$ & 15.81 & Non-resistant \\
\hline $\mathrm{T}_{1}$ & CCA type c & 6.00 & $2.02 \mathrm{a}$ & 14.78 & Very resistant \\
\hline $\mathrm{T}_{2}$ & IPG-F & 18.00 & $7.94 \mathrm{~b}$ & 23.35 & Resistant \\
\hline $\mathrm{T}_{3}$ & IPG-C & 9.00 & $3.78 \mathrm{a}$ & 24.84 & Very resistant \\
\hline $\mathrm{T}_{4}$ & IPG-C & 25.00 & $3.57 \mathrm{a}$ & 14.98 & Very resistant \\
\hline
\end{tabular}

Average values followed by different letters indicate significant differences (Tukey, $p<0.05$ )

The $\mathrm{T}_{2}$ series of Colatan IPG-F showed $7.94 \%$ weight loss differing from the control and the other treatments.

The $\mathrm{T}_{1}, \mathrm{~T}_{3}$ and $\mathrm{T}_{4}$ treatments did not show significant differences among themselves, with weight losses of $2.02 \%, 3.78 \%$ and $3.57 \%$ respectively.

Pinewood impregnated with protectives $\mathrm{T}_{1}, \mathrm{~T}_{2}, \mathrm{~T}_{3}$ and $\mathrm{T}_{4}$ behaved in the assay conditions as resistant to very resistant the fungal degradation (weight loss $0-10 \%$ ) when being exposed to the white rot fungus. The weight loss in the treatment with CCA type $\mathrm{c}$ disagrees with the values obtained by Bobadilla et al. (2007), with a weight loss of $9.51 \%$.

None of the assayed fungal strains degraded significantly the wood treated with CCA and Colatan IPG-C. In Colatan IPG-C low concentrations, colonization of the wood was observed but there were no symptoms of tissue degradation.

The CCA type $\mathrm{c}$ and IPG-C effectiveness to protect the P. elliottii wood was high for the treatments with 6 and $25 \mathrm{~kg} \mathrm{~m}^{-3}$ retention. These values assure the effectiveness of the substances in their protective function when applied to pine wood in an industrial way. 


\section{CONCLUSIONS}

Non-impregnated Pinus elliottii wood turned out to be more susceptible to a brown rot fungus than to a white rot fungus, behaving as not very durable wood when attacked by xylophagus fungi.

The CCA type c salt with $6 \mathrm{~kg} \mathrm{~m}^{-3}$ retention and the "quebracho colorado" extract based bioprotective reinforced with Colatan IPG-C mineral salts, at $25 \mathrm{~kg} \mathrm{~m}^{-3}$ retention in Pinus elliottii wood, increased resistance to fungal degradation by Gloeophyllum sepiarium and Pycnoporus sanguineus in lab assay conditions from non-resistant to very resistant, improving the inhibition of the biodegradation processes.

The protection observed would allow the use of this wood in high-risk conditions when it is impregnated with CCA type c, Colatan IPG-C (with the previously indicated retentions).

Colatan IPG-C bio-protective with a $9 \mathrm{~kg} \mathrm{~m}^{-3}$ wood retention, showed the same performance when compared to $25 \mathrm{~kg} \mathrm{~m}^{-3}$ retention, with the difference that surface mycelium growth was observed.

Colatan IPG-F bio-protective did not influence change pinewood resistance when confronting the brown rot fungus. However, it increased the type of resistance into resistant against the white rot fungus.

The "quebracho colorado" extract based bio-protective reinforced with mineral salts represents a viable and a more environmentally friendly alternative for protection and may extend the productive life of low durability wood against xylophagus fungi.

\section{REFERENCES}

ASTM International. 1981. D-2017. Standard method of accelerated laboratory test of natural decay resistance of wood. Society for testing and materials. Annual Book, pp 348-352.

Blanchette, R.; Nilsson, T.; Daniel, G.; Abad, A. 1990. Biological degradation of wood. Archaeological Wood 6: 141-174.

Bobadilla, E.A.; Suirezs, T.M.; Peryra, O.; Weber, E.; Silva, F.; Stehr, A. 2007. Durabilidad de la madera del Pinus taeda L. impregnado con arseniato de cobre cromatado, frente a hongos xilófagos, Misiones, Argentina. Floresta 37(1): 15-20.

Eaton, R.; Hale, M. 1993. Wood: Decay, pests and protection. Chapman \& Hall, London, p 546.

Eriksson, K.; Blanchette, R.; Ander, P.1990. Microbial and enzymatic degradation of wood and wood components. In: T.E. Timell, Editor, Springer Series in Wood Science, Springer-Verlag, Berlin, p 407.

FAO (Food and Agriculture Organization). 1986. Wood preservation manual. Mechanical wood products branch. Forest industries division. Rome, IT, FAO. Forestry Department, p 152.

Findlay W.P.K. 1951. The value of laboratory test on wood preservatives. (S1): Convention: British Wood Preserving Association. 
González Laredo, R.F. 1996. Preservación de Madera con Taninos. Madera y Bosques 2 (2):67-73.

Highley, T. 1983. Influence of type and amount of lignin on decay by Coriolus versicolor. Canadian Journal Forest Research 12: 435-438.

IRAM, Normalization and Accreditation Argentinean Institute. 1962. Norma IRAM 9518. Toxicidad, permanencia y eficacia de preservadores de madera. Métodos de laboratorio, pp 14.

IRAM, Normalization and Accreditation Argentinean Institute. 1998. Norma IRAM 9600. Preservación de maderas. Maderas preservadas mediante procesos con presión en autoclave. Instituto Argentino de Racionalización de Materiales, pp 22.

Keil, G.; Muface, M.; Luna, L. Acciaresi, G. 2006. Durabilidad de la madera de Polulus deltoides •Delta Gold· ("Stoneville 66") impregnada con metacrilato de metilo. Actas Jornadas de Salicáceas $339-345$.

Pearce, R.B. 1996. Antimicrobial defenses in the wood of living trees (Tansley Review No. 87). New Phytology 132:203-233.

Zabel, R.A.; Morrell, Y.J. 1992. Word microbiology. Decay and its prevention. Academics Press Inc, pp 476. 
